\title{
Archaeometric Analysis of Early Bronze Age Dark Rimmed Orange Bowl Ware (DROB ware) from the Upper Khabur (NE-Syria) and the Upper Tigris Valley (SE-Anatolia)
}

\author{
[YUKARI HABUR VE YUKARI DİCLE HAVZASINDA BULUNAN ERKEN TUNÇ \\ CAĞI "DARK RIMMED ORANGE BOWL WARE "(DROB WARE) SERAMİKLERIN \\ ARKEOMETRİK ANALIZZLERİ]
}

\author{
Mustafa KİBAROĞLU
}

\begin{abstract}
Anahtar Kelimeler
Erken Tunç Çă̆ı Seramikleri, Yukarı Dicle Havzası, Yukarı Habur Ha vzası, Arkeometrik Analiz, Seramik köken analizi.
\end{abstract}

\section{Keywords}

Early Bronze Age Pottery, Dark Rimmed Orange Bowl Ware, Upper Tigris Valley, Upper Khabur Valley, Archaeometric Analysis, Provenance Study.

\section{ÖZET}

Bu çalışmanın amacı, Güneydoğu Anadolu Bölgesi'ndeki Yukarı Dicle Havzasında ve Kuzey Suriye'deki Yukarl Habur Havzasında yapılan arkeolojik araştırmalarda ele geçen Erken Tunç dönemine ait Dark Rimmed Orange Bowl Ware (DROB-ware) mal grubunun, kimyasal ve petrografik analiz yöntemlerini kullanarak üretim yerinin belirlenmesidir. Bu amaçla, her iki bölgeden alınan DROB ware örneklerinin yanında, söz konusu seramiklerin üretiminde kullanılan muhtemel kil kaynak alanlarını tespit edebilmek için, her iki bölgeden çeşitli kil yataklarından örneklerde alınarak kimyasal ve petrografik analizleri yapılmuştır.

Arkeometrik analiz sonuçları, DROB ware'in Yukarı Dicle Havzasında, Bismil ve Batman arasında bulunan kil kaynaklarından üretildiğini, Yukarı Habur Havzasındaki höyüklerde bulunan örneklerin, bu bölgeye Yukarı Dicle Havzasından geldiğini göstermektedir.

\begin{abstract}
The Early Bronze Age Dark Rimmed Orange Bowl Ware (DROB ware) uncovered at various archaeological sites in the Upper Khabur (NE-Syria) and the Upper Tigris Valley (SE-Anatolia) were examined using X-ray fluorescence spectroscopy and petrographic thin section methods to determine chemical and mineralogical characteristics of the ware, with a view to determining the production place of the ware. To obtain information on possible area of clay sources used in their production, local clay samples from the distribution area of DROB ware in the Upper Tigris and the Upper Khabur Valley were used as reference material.

The results of archaeometric analysis suggests that the DROB ware belongs to the Upper Tigris Early Bronze Age ceramic tradition, produced from the local clays available between the province Bismil and Batman in the Upper Tigris Valley (SE-Anatolia) and traded to the Upper Khabur Valley in NE-Syria.
\end{abstract}




\section{Introduction}

Dark Rimmed Orange Bowls Ware (hereafter DROB ware; Fig. 1) is a distinct ware type of the Early Bronze Age found at several sites in the Upper Khabur region in Northeastern Syria and in the Upper Tigris Valley in the Southeastern Anatolia (Fig. 2). According to Jazira chronology, DROB ware is dated to the Akkadian and post-Akkadian periods, c. $2250-2000$ BCE. ${ }^{1}$ It is characterized macroscopically by the use of fine clay and a precisely executed surface treatment. The outer surface is covered by a thin slip with a color ranging from pale brown to orange, though orange is the most common color (Fig. 1). On the rim, all vessels have a slip in the form of a wide, dark stripe, usually brown to black in color (Fig. 1). The dark slip at the vessel rim, usually outer side but sometimes covering with a narrower stripe into the inner part, is intentional and generally associated with a particular shape, namely a semi-circular bowl with a smooth or pointed rim; most are thick-walled (up to $6 \mathrm{~mm}$ ), though there are also thin-walled (eggshell) examples. ${ }^{2}$ A clear picture of the geographical distribution of DROB ware in the Upper Tigris is still lacking, though the salvage excavations and surveys conducted in the region in recent years shows that its occurrence is more pronounced in the Upper Tigris compared to the Upper Khabur region ${ }^{3}$. It is quite clear that DROB ware displays a north-south oriented distribution pattern between the Upper Tigris Valley and the Upper Khabur region over the Tur' Abdin mountains (Fig. 2). According to the present state of the research, Tell Melebiya and Tell Bderi seems to be the southernmost sites within the Upper Khabur region that show the presence of DROB ware (Fig. 2). 4

In this paper, it is reported the results of the chemical and petrographic analysis carried out on thirty-six DROB ware sherds collected from the various sites in the Upper Khabur and in the Upper Tigris Valley (Fig. 2). An extensive collection of local clay samples $(n=79)$, initially collected as part of the SOAP project ${ }^{5}$ were used in this study as reference materials for the provenance identification of the ware. The main aim of the study

1 Bianchi 2012.

2 Bianchi 2012.

3 Bianchi 2012; Bianchi and Özfırat 2014

4 Bianchi 2012.

5 Kibaroğlu and Falb 2013. was to investigate the raw material source of DROB ware, and thus, to identify the production place of the ware. Further, the study also aimed to identify whether the ware was produced from a distinct clay source or used multi-clay sources. In addition, an attempt was also made to obtain some information on the production procedure of the ware, such as past preparation (levigation or temper) and firing temperature.

\section{Samples}

\subsection{DROB ware samples}

Thirty-six DROB ware sherds were selected for the chemical and petrographic analysis (Table 1). In the selection of the sherds, some macroscopic features such as the fineness of the ware (fine and coarse variants), wall thickness, and vessel shape were considered to assemble a representative sampling for the DROB Ware. The sampleset consists of examples unearthed at sites in the Upper Khabur region and in the Upper Tigris Valley: Tell Brak $(\mathrm{n}=3)$, Tell Mozan $(\mathrm{n}=14)$, Tell Arbid $(n=1)$ located in Upper Khabur; and Salat Tepe $(n=9)$, Kavuşan $(n=4)$, Çayırlık Tepe $(n=$ 2) and Susam Tepe $(n=2)$ located in the Upper Tigris Valley (Fig. 2). Most sherds come from archaeologically well-stratified deposits, while two samples, STP-1 and STP-2 from Salat Tepe, are from the surface collection (Table 1).

\section{2. Reference materials}

A total of 79 clay samples from different spots in the Upper Tigris $(\mathrm{n}=60)$ and Upper Khabur $(\mathrm{n}=19)$ that have been initially collected as a part of the SOAP project ${ }^{6}$ were considered in this study as reference materials for the comparison of the chemical and petrographic data of DROB ware (Fig.2). The samples from the Upper Tigris cover a large part of the clay deposits in the Valley; the majority come from the different terrace systems existing in the Upper Tigris, including the Batman River. ${ }^{7}$ They were mainly collected from beneath the agricultural soil at the terrace profiles (T4, T3, and T2), where it is considered that they were not chemically contaminated by anthropogenic activity. In the Karacadağ basaltic area, the samples were collected from in-situ occurred

6 Kibaroğlu and Falb 2013.

7 Doğan 2005. 
clay deposits by manual drilling from the deep between 0.6-1.5 m. From the Upper Khabur region, a total of 19 local clay samples from various riverbeds (wadies), including four samples from Derik/Mardin region, were also included as reference materials (Fig. 2). A modern ceramic fragment (sample QP-215) and its raw clay (QM1) that was taken from the local pottery workshop in al-Qamišli was also added to the reference group. According to the potter's information, the raw clay for QP-215 and QM1 was collected from the clay-rich deposits close to the workshop.

Before the analysis, coarse clays with large inclusions were first levigated in the laboratory at the University of Tübingen (Germany) using distilled water to obtain a fine clay fraction. Subsequently, samples were manually homogenized and prepared into about $4 \times 4 \times 2 \mathrm{~cm}$ briquettes and then fired in an electric kiln at a temperature between $800-850{ }^{\circ} \mathrm{C}$. A small part of clay briquettes was cut and ground into a fine powder using an agate mill and then submitted for chemical analysis.

\section{Analytical Methods}

\section{1. Wavelength dispersive X-ray fluorescence spectrometry (WDXRF)}

The major $\left(\mathrm{SiO}_{2}, \mathrm{Ti}_{2} \mathrm{O}, \mathrm{Al}_{2} \mathrm{O}_{3}, \mathrm{Fe}_{2} \mathrm{O}_{3}, \mathrm{MnO}\right.$, $\mathrm{MgO}, \mathrm{CaO}, \mathrm{Na}_{2} \mathrm{O}, \mathrm{K}_{2} \mathrm{O}, \mathrm{P}_{2} \mathrm{O}_{5}$ ) and trace element concentrations ( $\mathrm{Ba}, \mathrm{Co}, \mathrm{Cr}, \mathrm{Ni}, \mathrm{Rb}, \mathrm{Sr}, \mathrm{V}, \mathrm{Y}, \mathrm{Zn}$, $\mathrm{Zr}, \mathrm{Ce}, \mathrm{La}, \mathrm{Nd}, \mathrm{Sm}$, and $\mathrm{Yb}$ ) of the ceramic and reference samples were determined using a wavelength dispersive X-ray fluorescence spectrometer (Bruker AXS S4 Pioneer spectrometer, Rh $\mathrm{X}$-ray tube, $4 \mathrm{~kW}$ ) at the Institute of Geosciences, University of Tübingen (Germany) with 32 standardized samples. Analytical error and detection limits vary and depend on the element and uncertainties of sample composition. Uncertainties for all major elements are better than 1\% (1SD) and for the trace elements are better than 5\% (1SD).

Before grinding the ceramic samples to powder, a thin layer from internal and external surfaces of the sherds, which may have been chemically contaminated during the burial ${ }^{8}$ was removed by a diamond-coated saw. The ceramic and clay powders were then oven-dried at a constant

8 Wilson 1978; Schwedt et al. 2004. temperature of $105^{\circ} \mathrm{C}$ for 24 hours. The measurement was performed on glassy fused beads. For that, $1.5 \mathrm{~g}( \pm 0.003)$ of powder and $7.5 \mathrm{~g}( \pm 0.003)$ of flux (Merck spectromelt A12, a mixture of $66 \%$ Li-tetraborate and 34\% Li-metaborate) were mixed and subsequently fused at $1050{ }^{\circ} \mathrm{C}$ into a glassy fused bead to determine major and trace element concentrations. The loss-on-ignition (LOI) of the ceramic and clay samples was determined externally using $1 \mathrm{~g}$ of powder. The measured element concentrations were recalculated by normalizing the sum of the non-volatile oxides to $100 \%$. This procedure is required because a large part of the volatile components (LOI, mainly water and carbon dioxide) of the clays disappears during firing and is no longer present in the resulting ceramics. ${ }^{9}$

\subsection{Petrographic thin section analysis}

The petrographic analysis was carried out on thin sections from a total of 17 sherds from various sites in the Upper Khabur and the Upper Tigris valley. Thin sections were examined under a standard polarizing microscope at the Institute of Geosciences, University of Tübingen. Thin sections consist of fine and coarse variants and were from the different wall thicknesses found in both regions. This analysis was conducted to characterize the raw materials used in the DROB ware production and to identify the rock and mineral inclusions and other fabric features, to obtain information on the possible geographic location of the raw material source of the ware. Thin section analysis was also employed to identify, as far as possible, some technological aspects of production such as paste preparations and firing temperatures. A total of 24 reference samples, selected from different localities, including the Upper Tigris $(\mathrm{n}=18)$ and Upper Khabur $(\mathrm{n}=6)$, were also analyzed petrographically to compare their petrographic-mineralogical characteristics to those of DROB ware.

\section{Results}

\section{1. Major and trace element characteristics of the DROB ware}

The major and trace element concentrations of analyzed ceramic samples are given in Table 2 . Sample AA-208 could not be analyzed chemically

9 Ottenburgs et al. 1993. 
because of insufficient material but analyzed using the petrographic method. The major and trace element concentrations of DROB ware show some characteristic compositional patterns. Overall, the samples are characterized by average values of moderate $\mathrm{SiO}_{2}(56.1 \%), \mathrm{Al}_{2} \mathrm{O}_{3}(15.7 \%)$, $\mathrm{Na}_{2} \mathrm{O}(1.4 \%), \mathrm{K}_{2} \mathrm{O}(2.5 \%)$, and a relatively high $\mathrm{MgO}(5.2 \%)$ and $\mathrm{Fe}_{2} \mathrm{O}_{3}(7.8 \%)$ concentrations. $\mathrm{CaO}$ contents range from 6.1 to $19.1 \%$ indicate the use of moderate to high calcareous clays for the production of the vessels.

Major and trace element concentrations of the samples show some variations, particularly in major elements $\mathrm{Al}_{2} \mathrm{O}_{3}, \mathrm{MgO}, \mathrm{CaO}$, and trace elements $\mathrm{Ba}, \mathrm{Cr}, \mathrm{Ni}$, and $\mathrm{Ce}$, and less pronounced variations were also observed in $\mathrm{SiO}_{2}, \mathrm{Fe}_{2} \mathrm{O}_{3}, \mathrm{Co}$, $\mathrm{Rb}, \mathrm{Sr}, \mathrm{V}$, and $\mathrm{La}$. The other measured elements $(\mathrm{Y}, \mathrm{Zr}$, and $\mathrm{Nd}$ ) show more or less homogenous patterns. In figure 3, the bivariate plot of selected major and trace element concentrations of ceramic samples is illustrated. The concentration of $\mathrm{SiO}_{2}, \mathrm{CaO}, \mathrm{K}_{2} \mathrm{O}, \mathrm{Cr}, \mathrm{Ni}$, and element ratios of $\mathrm{Al}_{2} \mathrm{O}_{3} / \mathrm{Fe}_{2} \mathrm{O}_{3}$ and $\mathrm{Rb} / \mathrm{Cr}$ show different patterns that allow distinguishing the selected DROB samples into two main chemical groups. Sample AA-209, which is a typical DROB ware example, shows also a clear difference in major and trace elements composition from both main groups. As a whole, the first group, chemical group 1 (bivariate group 1), is characterized by higher $\mathrm{SiO}_{2}$, $\mathrm{Al}_{2} \mathrm{O}_{3}, \mathrm{~K} 2 \mathrm{O}, \mathrm{Rb}, \mathrm{Zr}$, slightly higher $\mathrm{Ba}, \mathrm{Ni}, \mathrm{Y}, \mathrm{Sm}$, $\mathrm{Yb}$, and lower $\mathrm{CaO}$ and $\mathrm{Sr}$ values, whereas the second group, chemical group 2 (bivariate group 2) contains higher $\mathrm{CaO}$, slightly higher $\mathrm{Sr}$, and lower $\mathrm{SiO}_{2}, \mathrm{Al}_{2} \mathrm{O}_{3}$, and $\mathrm{Zr}$ values.

Principal components analysis (PCA) of the ceramic samples was calculated on the basis of the values of five major $\left(\mathrm{SiO}_{2}, \mathrm{Al}_{2} \mathrm{O}_{3}, \mathrm{Na}_{2} \mathrm{O}\right.$, $\left.\mathrm{K}_{2} \mathrm{O}\right)$ and four trace elements $(\mathrm{Ba}, \mathrm{Cr}, \mathrm{Ni}$, and $\mathrm{V})$. The calculation of principal components was performed by JMP Software (v.13). Prior to the computation, the variables (elements) were transformed using the standard estimation method of JMP software. Other measured elements (Table 2) were removed from the data set as they show either large scattering $\left(\mathrm{TiO}_{2}\right.$, $\mathrm{Fe}_{2} \mathrm{O}_{3}, \mathrm{MgO}, \mathrm{Co}, \mathrm{Ni}, \mathrm{Rb}, \mathrm{Y}, \mathrm{Zn}, \mathrm{Ce}$, and $\mathrm{Sm}$ ) within the samples, low detection ( $\mathrm{Yb}$ ), or possible post-depositional contamination $(\mathrm{CaO}$, $\mathrm{P}_{2} \mathrm{O}_{5}$ ). The values of the first two principal components of the data (score plot) and loading plot are represented in Fig. 4a and b. The correlation of principal components, $\mathrm{PC} 1$ versus PC2, shows two main statistical groups within the ceramics data. These statistical groups largely, but not entirely, correspond with the chemical groups based on bivariate comparisons. The first group, chemical groups 1 (statistical group 1), consists of the samples collected from Tell Mozan (6), located in the Khabur Region, and Salat Tepe (6), Kavuşan (4) and Susam Tepe (1), located in the Upper Tigris Valley. The second group, chemical group 2, also consist of sherds collected from the sites in the Upper Khabur region: from Tell Mozan (7), Tell Brak (2), Tell Arbid (1), and from the sites in the Upper Tigris Valley; from Salat Tepe (1), Kavuşan (1) and Susam Tepe (2). Furthermore, groups of the statistical analysis contain DROB examples with different macroscopic features such as fine or coarse fabric and bowl shapes, so there is no correspondence between the statistical/ chemical groups and the macroscopic features of the examples belonging to each group.

The plot of the variable loadings, as displayed in Fig $4 b$, shows that statistical group 1 is mainly characterized by high concentrations of $\mathrm{Al}_{2} \mathrm{O}_{3}$, slightly high $\mathrm{K}_{2} \mathrm{O}$ and $\mathrm{Ba}$, and lower $\mathrm{Na}_{2} \mathrm{O}, \mathrm{Cr}$, and $\mathrm{Ni}$, whereas statistical group 2 shows reverse concertation values in these elements. There are few samples (e.g., AA-238, LN-10. AA-61, and AA-05) that are slightly separated from the main two groups as shown in Fig. 4a. This is apparently a result of slightly high $\mathrm{SiO}_{2}$ and $\mathrm{Na}_{2} \mathrm{O}$ and lower $\mathrm{V}$ for $\mathrm{AA}-238$ $\mathrm{LN}-10$ and AA-61 as well as higher $\mathrm{K}_{2} \mathrm{O}$ values for AA-205. Since they show more or less similar compositional patterns in most elements as observed in bivariate comparisons, they can be interpreted as subgroups of statistical group 1 rather than a separate clay source. As shown by the bivariate plot above, PCA also demonstrates that sample AA-2009 is clearly divided from other groups. This is not illustrated in the score plot as it plots out of the diagram area. As observed in bivariate and statistical analysis, DROB ware analyzed in this study are compositional inhomogeneous, and this can be particularly well-observed in elements $\mathrm{Al}_{2} \mathrm{O}_{3}$, $\mathrm{Fe}_{2} \mathrm{O}_{3}, \mathrm{Ba}, \mathrm{Co}, \mathrm{Cr}, \mathrm{Ni}, \mathrm{Rb}$, and La values. This inhomogeneous pattern may be the result of either natural concentration variation of the clay deposits or caused by paste preparation 
processes, for example by purification, but not verified in this study.

The results of the chemical analysis demonstrated above suggest that DROB ware excavated at the sites in the Upper Khabur and the Upper Tigris Valley belong to the same production tradition. The different compositional groups (statistical groups 1 and 2) point to the use of at least two different clay deposits for their production. The case of sample AA-209, which shows very different major and trace element compositions from both main groups, suggests the existence of a further chemical group and use of other clay sources for DROB ware production.

\section{2. Petrographic analysis of selected DROB ware samples}

The DROB ware samples selected for the petrographic analysis show that they were made of fine clays with inclusions varying from silt to coarse sand-size (about $0.05-1 \mathrm{~mm}$ ) in volume percentage from 3 to $20 \%$ (e.g., see Fig. $5 \mathrm{c}$ and $\mathrm{d})$. The main inclusions are quartz and muscovite as well as calcite and chert fragments in minor quantities that are present in different quantities in selected sherds. Single inclusion of feldspar, volcanic rock, and hornblende was also observed in a few samples. Quartz grains, as the predominant inclusion type, consist of well-sorted, angular, fine, sand-sized grains. Two quartz types were distinguished: monocrystalline and polycrystalline quartz with typical undulate extinction. The latter indicates its metamorphic origin. In some cases, the polycrystalline quartz shows intergrowths with muscovite, which also indicates its metamorphic origin. Muscovite inclusions, also abundant in the ware, are characterized by needle-like fragments with typical cleavage, low relief, and yellow-red or blue colors under polarized light. In some sherds, muscovite fragments show orientations parallel to the ceramic surface, which may indicate that the DROB ware was wheel-made. Further inclusion in minor quantities $(1-3 \%)$ is opaque grains with deep red color and high relief.

From a broad view, the selected DROB samples contain more or less similar types of inclusions; however, based on the grain size and general fabric features, they can be subdivided into two broad fabric groups. The first group, petrographic group A (PG-A), shows fine, partly very-fine fabric (e.g., AA-201), with main quartz and muscovite inclusions (Fig. 5ac). The grains are well-sorted and show serial distribution (Fig. 5). PG-A sherds comprise both fine and coarse variants of DROB vessels that are from both the Upper Khabur and the Upper Tigris Valley (Table 1). The second petrographic group, $\mathrm{PG}-\mathrm{B}$, is characterized by larger inclusions in higher quantities compared to PG-A (Fig. 5d-f). It also contains a slightly higher abundance of feldspar (1-2\%) and carbonate fragments. Likewise, PG-B comprises of DROB examples with fine and coarse paste variants that were collected from the sites in the Upper Khabur and Upper Tigris Valley (Table 1).

Comparing the chemical and petrographic results, it is seen that the groupings in each show no clear correspondence to each other. For example, statistical group 1 consists of samples belonging to petrographic groups $\mathrm{A}$ and $\mathrm{B}$, as is the same with statistical group 2 (Table 1). This suggests, on one hand, local inhomogeneity of the raw clays, containing slightly different amounts of inclusions that are possibly an effect of the sedimentation processes. On the other hand, this may also be a result of the purification process of the raw clay by potters. The finesse of the clay pastes and the absence of large single grains (bimodal grain size distribution) can be seen as an indication of purification processes (levigation) of the raw clay prior to the production.

In brief, the chemical and petrographic analyses of the DROB ware represented above yield that DROB sherds excavated in the Upper Khabur and in the Upper Tigris Valley belong to the same group of production from the same region. They were produced from different clay sources, using different processing (e.g., levigation). However, compositional linking, particularly petrographic results, and also chemistry suggest that the raw clay sources used for the production should be located within the same depositional environment, belonging to the similar hinterland geology and geographic location, as discussed below. 


\section{3. Provenance identification of the DROB ware}

\section{3. 1. Comparison of chemical analysis}

The main inclusions of the DROB ware, particularly muscovite and quartz (monocrystalline and polycrystalline types) as well as the moderate calcareous nature of the DROB ware, points to that the raw clay was derived mainly from quartz and muscovite rich, partly from calcareous rocks; thus, such rocks are exposed within the catchment area of the clay deposits. But both inclusions types are common in sediments and did not permit the ability to identify the clay source area of the DROB ware, specifically whether they are of the Upper Khabur or the Upper Tigris Valley origins. Therefore, the use of reference clay samples collected within the distribution area of the DROB ware became necessary.

The major and trace element concentration of the clay samples collected from various spots in the Upper Tigris and the Upper Khabur regions were compared using bivariate plots and multivariate statistical methods to examine the compositional similarities or dissimilarity of the DROB ware samples to the local clays and thus assign the ware to a distinct region. In figure 6 , the bivariate plots of selected elements $\left(\mathrm{SiO}_{2}, \mathrm{Al}_{2} \mathrm{O}_{3}, \mathrm{CaO}, \mathrm{Na}_{2} \mathrm{O}, \mathrm{Zr}\right.$ and $\left.\mathrm{V}\right)$, demonstrate that the clays from both regions show compositional variation but still allow a separation of the clays from the Upper Khabur and the Upper Tigris Valley. They form two broadly defined chemical groups, though for some elements (e.g., $\mathrm{TiO}_{2}, \mathrm{MgO}$, and $\mathrm{Nd}$, not shown) both groups show overlap. The clays from the Upper Tigris and the Upper Khabur region can be distinguished from each other in terms of the major elements $\mathrm{SiO}_{2}, \mathrm{Al}_{2} \mathrm{O}_{3}$, $\mathrm{CaO}, \mathrm{Fe}_{2} \mathrm{O}_{3}, \mathrm{Na}_{2} \mathrm{O}$, and trace elements $\mathrm{Ni}, \mathrm{V}$, and $\mathrm{La}$, though the groups are not separated from each other. The Upper Tigris clays, considered in this study, are characterized by an average higher concentration of $\mathrm{SiO}_{2}(56.6 \%)$, $\mathrm{Al}_{2} \mathrm{O}_{3}(15.5 \%), \mathrm{Fe}_{2} \mathrm{O}_{3}(6.9 \%), \mathrm{Na}_{2} \mathrm{O}(1.3 \%), \mathrm{Ni}$ (190.8 ppm), V (151.2 ppm), and La (24.1 ppm) and lower $\mathrm{CaO}(12.6 \%)$ and $\mathrm{Sr}(222.1 \mathrm{ppm})$ compared to the Upper Khabur clays analyzed in this study. A comparison of these results to the DROB ware in bivariate plots as illustrated in figure 6 revealed that the DROB Wares show a closer compositional similarity to the Upper Tigris clays than to the Upper Khabur region, both in the major and trace elements. A similar result was achieved also by using multivariate statistical analysis as presented below.

To test the results of bivariate plots and to refine compositional group patterns of the clay samples from the Upper Tigris Valley and Upper Khabur region, and accordingly to indicate their similarity or dissimilarity to DROB Ware, the entire compositional data were calculated using principal component analysis (PCA). PCA was calculated on the base of four major elements $\left(\mathrm{SiO}_{2}, \mathrm{Al}_{2} \mathrm{O}_{3}, \mathrm{Fe}_{2} \mathrm{O}_{3}\right.$, and $\left.\mathrm{Na}_{2} \mathrm{O}\right)$ and five trace elements (Ba, Cr, Ni, V, Y, La) that are considered in this study as suitable for achieving the aims of the analysis. The major elements $\mathrm{CaO}$ and $\mathrm{P}_{2} \mathrm{O}_{5}$ were removed from the data set as their initial concentrations can be modified in the post-depositional environment. ${ }^{10}$ The elements of $\mathrm{TiO}_{2}, \mathrm{MgO}, \mathrm{Co}, \mathrm{Rb}$, and $\mathrm{Ce}$ were also removed from the data set as they show either large scattering within the whole data set or due to low detection $(\mathrm{Yb})$. Concentrations of $\mathrm{Zn}, \mathrm{Nd}$, and $\mathrm{Sm}$, which showed unusual concentration shift that may be a result of measurement error, were also removed from the data.

The results of the first two principal components (PC 1 and PC 2), accounting for the 54,5\% of the total variance, are shown in a scatterplot in figure $7 \mathrm{a}$ and the loading plot of the selected variables in figure $7 \mathrm{~b}$. The PCA allows to separate the clays from the Upper Tigris and from the Upper Khabur region, clustered into two main groups which mostly correspond with the sampling regions of the Upper Tigris and the Upper Khabur. However, the groups' separation is not sharp; there is overlapping but still broadly defined groups for both regions. The loading of selected elements as shown in figure $7 \mathrm{~b}$ indicates that $\mathrm{SiO}_{2}, \mathrm{Al}_{2} \mathrm{O}_{3}, \mathrm{Na}_{2} \mathrm{O}, \mathrm{Ba}$ and $\mathrm{V}$ dominate the Upper Tigris clays, while La is the most dominant parameters in the Upper Khabur clays. In the scatter plot of the first two PCs, the DROB ware shows closer compositional similarity to the Upper Tigris clays compared to those from the Upper Khabur region and suggests that the Upper Tigris Valley is most probable source area of the raw

10 Freestone et al. 1985; Schwedt et al. 2004. 
material, thus the production place of DROB Ware. However, due to the compositional similarity of the clay samples collected in the various spots within the Upper Tigris Valley (Fig. 2 ), it is not possible to assign the DROB ware to a more precise geographical location or clay source area.

Taking into account of the results of the chemical analysis using bivariate and multivariate statistical evaluation, the possible clay sources for the DROB ware may be located between the province Bismil and Batman in the Upper Tigris Valley (Fig. 2). This result is also supported by petrographic analysis as presented below.

\section{4. 3. Comparison of the petrographic analysis}

A total of 23 thin sections were prepared from the reference clays from both regions, including thirteen from the Upper Tigris Valley, two from Derik/Mardin (southern slope of Tur'Abdin), and three samples from the Upper Khabur region. The clays from the Upper Tigris Valley contain mainly quartz and muscovite in varying quantities (Fig. 8a-c). Further inclusions are carbonate, biotite, plagioclase, chert, and reddish opaque minerals in minor quantities. Quartz grains were angular in shape; the large grains show polycrystalline structure and undulate extinction, which points to a metamorphic origin such as gneiss or slate. Such rocks are exposed on the Eastern Taurus mountains to the north of the Upper Tigris in so-called Bitlis-Pütürge metamorphics. This may also explain the presence of muscovite inclusions in the Upper Tigris clays. Petrography of the Upper Tigris clays show also the iron-rich nature of the clays that is represented by the reddish color of the clay paste under oxidizing firing atmosphere. In contrast, the clay samples from the Upper Khabur area (Fig. 8d-f) show different fabric features. Thin sections from four samples (HN2S, VS1-VS-2 and GM1) show a marly clay matrix and are characterized by low quartz and a high quantity of carbonate inclusions, as also attested by their high $\mathrm{CaO}$ values mentioned above. No muscovite was observed in the Upper Khabur clays.

Comparing the petrographic characteristics of the DROB ware with those of the clay reference samples, it is evident that the DROB ware show closer petrographic similarity to the Upper Tigris clay than the Upper Khabur clays, which supports the results of the elemental analysis discussed above, and reinforce the Upper Tigris origin of DROB ware.

\section{Discussion and conclusions}

Archaeometric analysis carried out on DROB ware samples $(n=36)$ collected from the various sites in the Upper Khabur and the Upper Tigris Valley reveal valuable information contributing to a better understanding of the cultural and trade relations of two Early Bronze Age communities in the Upper Khabur (Northeastern Syria) and the Upper Tigris Valley (Southeastern Anatolia). DROB ware unearthed in the Upper Khabur and the Upper Tigris Valley were produced from raw materials of the same source area, characterized by moderate to high calcareous nature with moderate to high iron oxide content, which is possibly the reason for their reddish color when fired under oxidation conditions. DROB ware found in both regions show no differences either in their chemical and petrographic-mineralogical compositions, suggesting that they all belonged to the same production tradition and originated from the same geographic area.

Combining the results of both analytical methods and the comparison of the results to the clay reference groups from both regions indicate that the DROB ware was manufactured from the clay sources available in the Upper Tigris Valley. In this study, two main clay sources with local variations in their element contents exploited for DROB ware production were distinguished. Moreover, as shown by sample AA-209, there are further deposits that were also used for DROB production. However, it is difficult to assign the location of the clay sources more precisely within the Upper Tigris Valley from their chemical and petrographic characteristics. This is due to the compositional similarities of the clays in the Valley, which may be attributed to the similar hinterland surface geology of the catchment and the sedimentation conditions of the clay deposits. In the Upper Tigris Valley, there are several fluvial terraces ${ }^{11}$ containing rich clay deposits with high plasticity. For DROB ware, potters may have exploited various raw clays deposited in the terraces available in a large area between the

11 Doğan 2005. 
province of Bismil and the Batman River.

Petrographic analysis gives some further information on the production technique of the ware. Orientation of the needle-like muscovite fragments parallel to the ceramic surface observed in thin sections (e.g., clearly visible at the samples AA-212) suggest that the DROB ware was wheelmade. The presence of calcite and absence of any vitrification, as well as the general optic appearance of the clay matrix, are suggestive of a firing temperature lower than $850^{\circ} \mathrm{C} .12$

The presence of the materials produced in the Upper Tigris, in this case DROB ware, indicates an interregional exchange network existing between the Upper Tigris Valley and the Upper Khabur. The presence of North Mesopotamians in the Upper Tigris is already attested by archaeological records, for example by the victory stela of Akkadian king Naram-Sin discovered in Pir Hüyesin (dated to c. 2250 BCE), located to the northeast of Diyarbakir (Fig. 2). ${ }^{13}$ KellyBuccellati ${ }^{14}$ has argued that the regions north and south of the Tur 'Abdin Mountains were in commercial contact, based mainly on the trade of copper, a highly sought-after material in the whole Syro-Mesopotamian region in the third millennium BC. The north-south oriented distribution pattern of DROB ware, as a narrow strip over the Tur' Abdin, is indicative of a communication route of the Tigridian and North Mesopotamian communities in the Bronze Age. Accordingly, it can be proposed that the DROB ware was traded through the Tur' Abdin.

The first appearance of DROB ware in the Upper Khabur is dated to the Early Jazira $3 a-3 b$ period (c. $2500 \mathrm{BCE}$ ), intensified in period EJZ $4-5$, c. $2220 \mathrm{BCE}, 15$ and after that, disappeared from the region. Its disappearance in the Upper Khabur overlaps chronologically with the crisis of Northern Mesopotamian urbanism, which is characterized by drastic change in the urban system in Northern Mesopotamia. This event, as known also $4.2 \mathrm{ka}$ event ${ }^{16}$ was the subject of various works and has been controversially

12 Cultrone et al. 2001.

13 See Ökse 2011; Bianchi 2012.

14 Kelly-Buccellati 1990; see also Buccellati and KellyBuccellati 1999.

15 Bianchi and Özfirat 2014.

16 Weiss et al.1993. discussed. ${ }^{17}$ The disappearance of DROB ware in the Upper Khabur may be related, directly or indirectly, to this urban crisis, which led to interruption of the exchange system existing between the Upper Tigris and the Upper Khabur region. However, this interpretation is based on the very limited data represented in this study, and further evidence is required to substantiate the potential relation between the disappearance of the DROB ware in the Upper Khabur region and the urban crisis in Northern Mesopotamia.

\section{Acknowledgements}

I want to express my gratitude to the following colleagues and the institutes for collaboration and contributions to the work: Kültür Varlıkları ve Müzeler Genel Müdürlüğü in Ankara, Nevin Soyukaya and Ahmet Duman (Diyarbakır Museum), Prof. Dr. Muharrem Satır, (Germany), Dr. Alice Bianchi (Qatar), Dr. Deniz Yaşın-Maier (Swiss), Dr. Heinrich Taubald (Germany), Prof. Dr. Tuba Ökse (Turkey) and Prof. Dr. Gülriz Kozbe (Turkey). I would like also to thank the anonymous reviewers for their carefully reading of the manuscript and valuable comments and suggestions. This study was a part of my $\mathrm{PhD}$ thesis and the SOAP research project funded by the German Research Foundation (DFG).

\section{References}

Bianchi 2012: A. Bianchi, A., Comparative studies on the pottery of sector AK of the royal building in Tell Mozan Urkes (Syria). Wiesbaden: Harrassowitz.

BiAnchi and Özfırat 2012: A. Bianchi and A. Özfırat, A., Dark Rimmed Orange Bowl Ware. In: Lebeau, M. (ed.), Archen International. Ceramics, Vol.1, Brepols, 271-276.

Buccellati and Kelly-Buccellati 1999: G. Buccellati, M. Kelly-Buccellati, "Das archaäologische Projekt Tall Mozan/Urkeš”, MDOG 131, 7-16.

Cultrone et al. 2001: G. Cultrone, C. RodriguezNavarro, E. Sebastián Pardo, O. Cazalla, M.J. De la Torre López, M.J., "Carbonate and silicate phase reactions during ceramic firing”. European Journal of Mineralogy, 13, 621-634.

DoğAn2005:U.Doğan,U., "Holocenefluvialdevelopment of the Upper Tigris Valley (Southeastern Turkey) as documented by archaeological data". Quaternary International 129, 75-86.

17 See e.g., Weiss et al. 1993; Kuzucuoğlu and Marro 2007; Wossink 2009; Weiss 2000; Pfälzner 2012; Ur 2015. 
Freestone et al. 1985: I.C. Freestone, N.D. Meeks, P. Middleton, "Retention of phosphate in buried ceramics: an electron microbeam approach". Archaeometry 27 (2), 161-177.

Kelly-Buccellati 1990: M. Kelly-Buccellati, "Trade in Metals in the Third Millennium: Northeastern Syria and Eastern Anatolia". In: P. Matthiae - M. N. van Loon - H. Weiss (eds.), Resurrecting the Past. Leiden, Nederlands Institut voor het Nebije Osten, $17-40$.

KibaroĞLU and Falb 2013: M. Kibaroğlu and Ch. Falb, "The Frankfurt University's Southeast Anatolia Project (SOAP): Archaeometric investigations on Early Bronze Age pottery". Applied Clay Science 82, 53-61.

KuzucuoĞLu and Marro 2007: C. Kuzucuoğlu, C. Marro, "Sociétés humaines et changement climatique à la fin du troisième millénaire: une crise a-t-elle eu lieu en Haute Mésopotamie ?» Actes du Colloque de Lyon, 5-8 déc. 2005 (Vara Anatolica $X I X)$, Institut français d'études anatoliennes Georges-Dumézil, Istanbul.

Meier-Yaşın 2015: D. Meier-Yaşın, Zwischen Anatolien und Mesopotamien: Kulturaustausch in der Mittelbronzezeit am oberen Tigris anhand der Keramik vom Salat Tepe, Südost-Türkei (unpublishe $\mathrm{PhD}$ tehsis), University of Bern. Switzerland

Ottenburgs et al. 1993: R. Ottenburgs, C. Jorissen, W. Viaene, Sagalassos Ware IV. Study of the clays. In: Waelkens, M. (Ed.), Sagalassos I. First General Report on the Survey (1986-1989) and Excavations (1990-1991). Acta Archaeologica Lovaniensia Monographiae 5, Leuven, 163-170.

ÖKSE 2011: A.T. Ökse, "The early bronze age in Southeastern Anatolia". In: Steadman SR, McMahon G (eds) The Oxford handbook of ancient Anatolia. Oxford University Press, New York, 260-289.

PfäLZner 2012: P. Pfälzner, "Household Dynamics in Late Third Millennium Northern Mesopotamia". In: Weiss, H., (ed.), Seven generations since the fall of Akkad. Wiesbaden: Harrassowitz Verlag, 145-162.

Schwedt et al. 2005: A. Schwedt, M. Mommsen, N. Zacharias, "Post-depositional elemental alter- ations in pottery activation analysis of surface samples". Archaeometry 46, 85-101.

WiLson 1978: A.L. Wilson, "Elemental analysis of pottery in the study of its provenance: a review". Journal of Archaeological Science 5, 219-236.

Weiss et al. 1993: A. Weiss, M.A. Courty, W. Wetterstrom, F. Guichard, L.M. Senior, R. Meadow, A. Curnow, "The genesis and collapse of third millennium north Mesopotamian civilization”. Science 261, 995-1004.
Weiss 2000: H. Weiss, "Beyond the Younger Dryas. Collapse as adaptation to abrupt climate change in ancient West Asia and the Eastern Mediterranean". In: G. Bawden and R.M. Reycraft (eds.): Environmental disaster and the archaeology of human response. Anthropological Papers, 7. Albuquerque, 75-98.

Wossink 2009: A. Wossink, Challenging Climate Change: Competition and Cooperation Among Pastoralists and Agriculturalists in Northern Mesopotamia (c. 3000-1600 BC). Sidestone Press.

Makale Gönderim Tarihi: 11.01.2021

Makale Kabul Tarihi: 09.02.2021

\section{MUSTAFA KİBAROĞLU}

Orcid ID: 0000-0002-5294-2783

Institute for Pre-and Protohistory and Medieval Archaeology, Eberhald-Kars University of Tübingen/GERMANY.

kibaroglu@gmail.com 


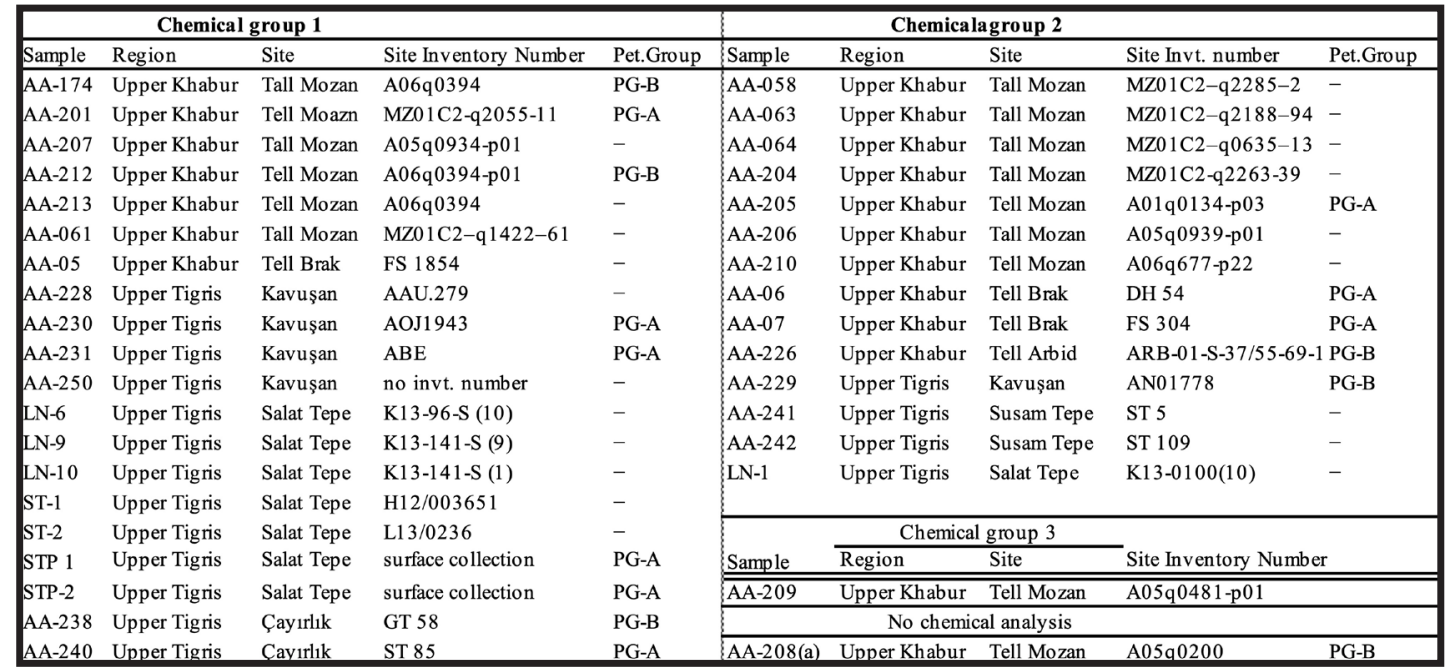

Table 1. Chemical and petrographic groups of the analyzed DROB ware samples from both regions, and their site inventory numbers. A full description and documentation are given in Bianchi (2012) and YaşınMeier (2015). *Sample AA-2008 could not be analyzed chemically due to small amount of available material.

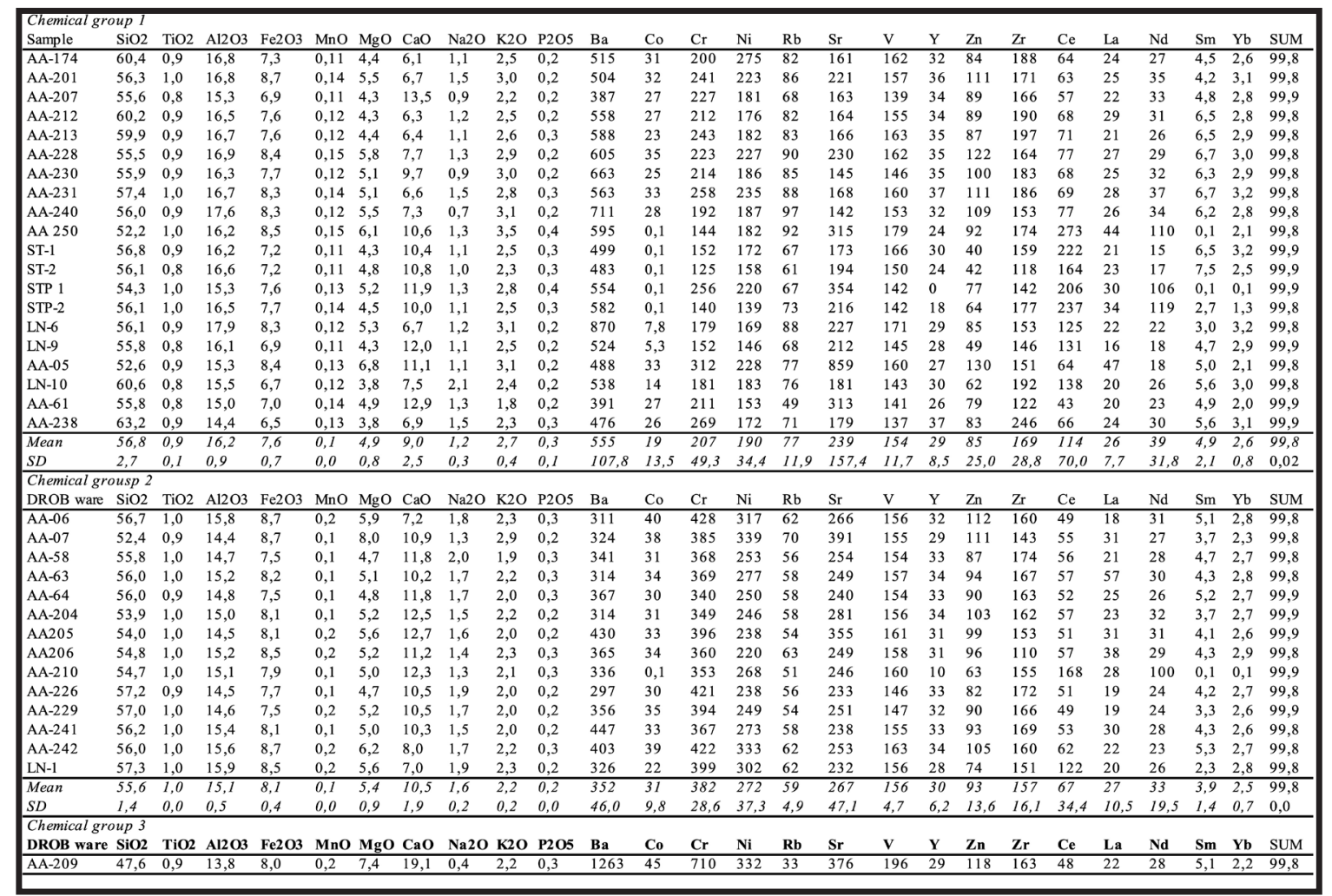

Table 2. The major and trace element concentrations of DROB ware sherds from the Upper Tigris Valley and the Upper Khabur region. Concentration values are given in $\mathrm{Wt}$. \% for major and trace elements in ppm. (Mean: average concentration values of group, SD standard deviation). 


\begin{tabular}{|c|c|c|c|c|c|c|c|c|c|c|c|c|c|c|c|c|c|c|}
\hline Sample & $\mathrm{SiO} 2$ & $\overline{\mathrm{TiO} 2}$ & $\overline{\mathrm{Al} 2 \mathrm{O} 3}$ & $\mathrm{Fe} 2 \mathrm{O} 3$ & $\begin{array}{l}\mathrm{MnO} \\
\end{array}$ & $\mathrm{MgO}$ & $\mathrm{CaO}$ & $\mathrm{NaO}$ & K2O & P205 & $\overline{\mathrm{Ba}}$ & $\overline{\bar{C}}$ & $\overline{\overline{C_{\mathrm{r}}}}$ & $\overline{\mathrm{Ni}}$ & $\overline{\mathrm{Rb}}$ & $\overline{\mathrm{Sr}}$ & $\overline{\mathrm{V}}$ & $\overline{\mathrm{Y}}$ \\
\hline T106 & 57,1 & 0,9 & 15,1 & 9,0 & 0,13 & 6,2 & 7,0 & 2,41 & 1,8 & 0,19 & 298 & 45,0 & 646 & 287 & 49 & 204 & 163 & 30 \\
\hline TFB & 56,1 & 0,9 & 14,9 & 8,1 & 0,13 & 5,4 & 10,4 & 1,95 & 1,8 & 0,16 & 285 & 31,0 & 435 & 234 & 56 & 201 & 156 & 28 \\
\hline YY-1 & 54,7 & 0,9 & 15,0 & 7,6 & 0,18 & 5,3 & 13,2 & 1,21 & 1,6 & 0,16 & 385 & 32,0 & 227 & 120 & 51 & 224 & 159 & 28 \\
\hline YY-2 & 57,5 & 0,9 & 15,3 & 7,9 & 0,14 & 5,6 & 9,3 & 0,94 & 2,1 & 0,20 & 401 & 25,0 & 270 & 163 & 75 & 174 & 186 & 30 \\
\hline T432 & 52,7 & 0,9 & 14,00 & 7,3 & 0,14 & 4,5 & 17,2 & 1,44 & 1,4 & 0,16 & 268 & 21,0 & 603 & 305 & 48 & 246 & 158 & 21 \\
\hline TD-B & 56,9 & 1,0 & 14,1 & 7,7 & 0,12 & 5,3 & 10,8 & 2,29 & 1,5 & 0,14 & 263 & 8,40 & 812 & 309 & 44 & 171 & 159 & 33 \\
\hline T471 & 61,5 & 1,1 & 15,1 & 7,9 & 0,14 & 4,6 & 5,1 & 2,53 & 1,7 & 0,17 & 275 & 24,0 & 1039 & 306 & 50 & 164 & 170 & 27 \\
\hline $\mathrm{T} 470$ & 56,1 & 1,0 & 17,9 & 9,2 & 0,15 & 6,7 & 6,5 & 0,59 & 1,7 & 0,15 & 309 & 27,0 & 217 & 207 & 54 & 187 & 213 & 20 \\
\hline T466 & 53,5 & 1,1 & 16,1 & 8,4 & 0,15 & 4,2 & 14,5 & 0,45 & 1,4 & 0,12 & 414 & 23,0 & 315 & 226 & 59 & 178 & 180 & 28 \\
\hline T467 & 63,0 & 1,1 & 17,2 & 8,5 & 0,17 & 4,7 & 2,1 & 1,35 & 1,6 & 0,16 & 257 & 36,0 & 532 & 309 & 55 & 118 & 167 & 24 \\
\hline T465 & 54,3 & 1,0 & 14,3 & 7,4 & 0,14 & 5,1 & 14,2 & 1,57 & 1,6 & 0,17 & 316 & 17,0 & 591 & 268 & 50 & 235 & 159 & 21 \\
\hline UT1B & 39,4 & 0,7 & 9,18 & 4,9 & 0,10 & 6,1 & 37,1 & 0,66 & 1,3 & 0,41 & 208 & 4,00 & 305 & 102 & 38 & 387 & 111 & 33 \\
\hline UCT-1 & 43,1 & 0,8 & 10,6 & 5,7 & 0,11 & 5,5 & 31,5 & 0,82 & 1,4 & 0,36 & 246 & 17,0 & 346 & 96 & 45 & 332 & 120 & 28 \\
\hline UCT2 & 52,6 & 0,9 & 14,4 & 7,2 & 0,14 & 4,7 & 17,5 & 0,58 & 1,7 & 0,22 & 367 & 24,0 & 254 & 160 & 72 & 203 & 138 & 34 \\
\hline T399 & 57,8 & 1,0 & 15,2 & 7,5 & 0,18 & 4,1 & 11,3 & 0,80 & 1,7 & 0,19 & 333 & 21,0 & 406 & 241 & 67 & 162 & 159 & 29 \\
\hline $\mathrm{T} 400$ & 59,8 & 1,1 & 16,4 & 8,0 & 0,18 & 4,5 & 6,9 & 0,90 & 1,8 & 0,20 & 333 & 24,0 & 407 & 266 & 72 & 122 & 172 & 29 \\
\hline TGT20 & 55,3 & 1,0 & 15,6 & 7,5 & 0,13 & 4,4 & 13,7 & 0,56 & 1,4 & 0,14 & 379 & 16,0 & 390 & 229 & 65 & 227 & 163 & 28 \\
\hline T458 & 50,6 & 1,0 & 14,2 & 6,8 & 0,14 & 6,8 & 17,5 & 0,63 & 1,8 & 0,21 & 359 & 12,0 & 308 & 245 & 68 & 202 & 162 & 29 \\
\hline GRC5 & 51,9 & 0,8 & 14,4 & 7,9 & 0,15 & 5,3 & 16,5 & 0,90 & 1,7 & 0,25 & 301 & 35,0 & 253 & 202 & 58 & 377 & 156 & 26 \\
\hline GRC2 & 55,2 & 0,9 & 14,9 & 8,4 & 0,16 & 5,1 & 12,1 & 1,07 & 1,6 & 0,31 & 345 & 35,0 & 503 & 191 & 66 & 247 & 131 & 30 \\
\hline GRC4 & 53,0 & 1,0 & 15,9 & 10,6 & 0,19 & 8,0 & 7,4 & 1,64 & 1,9 & 0,19 & 353 & 78,0 & 591 & 364 & 64 & 190 & 171 & 30 \\
\hline T456 & 53,8 & 0,8 & 14,9 & 6,9 & 0,14 & 4,8 & 16,1 & 0,93 & 1,3 & 0,12 & 356 & 12,0 & 240 & 149 & 45 & 313 & 168 & 19 \\
\hline T462 & 56,9 & 1,0 & 14,2 & 7,5 & 0,14 & 5,1 & 10,8 & 2,33 & 1,7 & 0,18 & 318 & 20,0 & 650 & 195 & 49 & 273 & 159 & 23 \\
\hline T463 & 54,4 & $\mathbf{0 , 9}$ & 14,9 & 7,1 & 0,14 & 4,4 & 14,8 & 0,66 & 2,3 & 0,20 & 349 & 8,0 & 308 & 218 & 80 & 196 & 145 & 27 \\
\hline T464 & 53,7 & $\mathbf{0 , 9}$ & 14,9 & 7,2 & 0,14 & 4,4 & 15,5 & 0,64 & 2,3 & 0,19 & 353 & 5,0 & 299 & 199 & 80 & 212 & 152 & 24 \\
\hline $\mathrm{T} 405$ & 54,1 & 0,8 & 13 & 5,9 & 0,11 & 4,0 & 17,8 & 0,79 & 3,1 & 0,26 & 342 & 0,0 & 206 & 157 & 63 & 217 & 151 & 21 \\
\hline T461 & 52,1 & 0,8 & 15,5 & 7,1 & 0,13 & 5,1 & 16,7 & 0,45 & 1,7 & 0,13 & 367 & 10,0 & 252 & 201 & 70 & 297 & 158 & 22 \\
\hline SLT1 & 56,7 & 0,9 & 13,6 & 7,1 & 0,13 & 5,0 & 11,9 & 2,07 & 2,3 & 0,17 & 278 & 8,0 & 401 & 253 & 49 & 252 & 158 & 30 \\
\hline SLT2 & 62,5 & 1,0 & 12,2 & 6,7 & 0,09 & 3,8 & 9,4 & 2,24 & 1,6 & 0,20 & 296 & 6,0 & 888 & 197 & 45 & 195 & 148 & 37 \\
\hline $\mathrm{T} 401$ & 54,1 & 0,9 & 17,3 & 8,0 & 0,14 & 5,1 & 11,9 & 0,23 & 2,0 & 0,16 & 372 & 12,0 & 214 & 245 & 88 & 180 & 160 & 29 \\
\hline TGT22 & 61,7 & 0,7 & 14,4 & 5,7 & 0,09 & 4,1 & 9,8 & 1,42 & 1,8 & 0,18 & 388 & 0,0 & 133 & 106 & 56 & 155 & 133 & 20 \\
\hline T455 & 55,1 & 1,0 & 13,9 & 7,1 & 0,14 & 5,3 & 13,9 & 1,78 & 1,5 & 0,15 & 289 & 22,0 & 612 & 257 & 47 & 277 & 156 & 21 \\
\hline T459 & 57,8 & 0,8 & 13,9 & 6,0 & 0,12 & 4,2 & 14,2 & 1,35 & 1,5 & 0,13 & 391 & 5,0 & 205 & 121 & 48 & 260 & 147 & 19 \\
\hline T460 & 59,9 & 0,9 & 14,2 & 5,9 & 0,12 & 3,6 & 12,2 & 1,19 & 1,7 & 0,14 & 450 & 8,0 & 216 & 141 & 61 & 296 & 140 & 26 \\
\hline SLT3 & 62,2 & 0,8 & 14,8 & 6,2 & 0,10 & 3,7 & 7,9 & 1,95 & 2,0 & 0,19 & 393 & 0,0 & 162 & 147 & 64 & 153 & 129 & 30 \\
\hline SLT4 & 68,8 & 0,7 & 13,8 & 5,2 & 0,09 & 3,0 & 3,8 & 2,37 & 1,9 & 0,14 & 450 & 0,0 & 140 & 118 & 56 & 136 & 120 & 26 \\
\hline T410 & 56,5 & 0,9 & 16,2 & 7,4 & 0,14 & 4,6 & 11,4 & 0,52 & 2,1 & 0,18 & 425 & 8,0 & 239 & 224 & 86 & 182 & 154 & 28 \\
\hline MUT2 & 55,4 & 0,9 & 14,9 & 7,0 & 0,13 & 5,2 & 13,5 & 1,05 & 1,8 & 0,17 & 357 & 1,0 & 219 & 178 & 60 & 217 & 152 & 27 \\
\hline MUT3 & 56,8 & 0,8 & 13,6 & 6,4 & 0,13 & 4,8 & 14,2 & 1,21 & 1,7 & 0,19 & 327 & 0,0 & 227 & 159 & 53 & 205 & 156 & 31 \\
\hline MUT4 & 54,0 & 0,8 & 12,7 & 6,2 & 0,12 & 4,7 & 18,0 & 1,31 & 1,7 & 0,42 & 304 & 0,0 & 225 & 134 & 46 & 309 & 142 & 23 \\
\hline $\mathrm{T} 452$ & 55,1 & 0,9 & 15,3 & 7,6 & 0,15 & 5,8 & 11,2 & 1,79 & 1,8 & 0,19 & 371 & 19,0 & 370 & 258 & 57 & 283 & 169 & 24 \\
\hline T453 & 55,3 & 0,9 & 15,1 & 7,4 & 0,15 & 5,5 & 11,6 & 1,56 & 2,0 & 0,20 & 328 & 18,0 & 364 & 245 & 55 & 246 & 170 & 23 \\
\hline T454 & 54,5 & 0,9 & 15,4 & 7,7 & 0,15 & 5,5 & 12,1 & 1,53 & 1,9 & 0,18 & 389 & 18,0 & 338 & 252 & 59 & 263 & 172 & 22 \\
\hline DRK1 & 55,0 & $\mathbf{0 , 8}$ & 14,7 & 6,7 & 0,14 & 4,5 & 15,7 & 0,90 & 1,3 & 0,13 & 345 & 11,0 & 231 & 146 & 50 & 358 & 152 & 21 \\
\hline T600 & 65,7 & 0,9 & 13,4 & 5,4 & 0,13 & 2,8 & 7,9 & 1,80 & 1,8 & 0,14 & 440 & 4,0 & 183 & 152 & 61 & 146 & 127 & 27 \\
\hline T602 & 45,4 & 0,6 & 12,6 & 5,3 & 0,09 & 3,3 & 30,2 & 0,83 & 1,4 & 0,11 & 439 & 51,0 & 113 & 88 & 47 & 208 & 121 & 21 \\
\hline T414 & 61,0 & 0,9 & 16,2 & 7,2 & 0,09 & 4,1 & 6,0 & 1,42 & 2,7 & 0,19 & 444 & 7,0 & 162 & 164 & 86 & 122 & 156 & 29 \\
\hline $\mathrm{TN}-21$ & 55,8 & 0,9 & 14,6 & 6,7 & 0,13 & 4,7 & 14,3 & 0,81 & 1,8 & 0,14 & 403 & 7,0 & 230 & 186 & 69 & 234 & 145 & 27 \\
\hline BTM1 & 54,4 & 0,8 & 15,2 & 6,9 & 0,16 & 5,3 & 13,9 & 1,23 & 1,8 & 0,15 & 198 & 12,0 & 254 & 159 & 47 & 283 & 200 & 19 \\
\hline BTMI I & 61,9 & 0,7 & 14,1 & 5,9 & 0,10 & 4,2 & 9,2 & 1,69 & 1,9 & 0,14 & 267 & 3,0 & 198 & 135 & 60 & 224 & 140 & 18 \\
\hline BTM10 & 50,1 & 0,7 & 13,7 & 6,3 & 0,13 & 4,1 & 21,9 & 1,14 & 1,7 & 0,13 & 447 & 0,0 & 128 & 102 & 54 & 247 & 182 & 22 \\
\hline BTM3 & 53,2 & 0,7 & 13,6 & 6,1 & 0,31 & 4,8 & 17,8 & 1,30 & 1,8 & 0,13 & 671 & 11,0 & 188 & 133 & 54 & 397 & 173 & 15 \\
\hline B TM9 & 62,7 & 0,7 & 14,1 & 5,4 & 0,10 & 3,5 & 9,6 & 1,75 & 1,9 & 0,13 & 514 & 0,0 & 122 & 100 & 62 & 248 & 118 & 21 \\
\hline BTM4 & 61,0 & 0,9 & 14,2 & 6,1 & 0,09 & 2,9 & 12,0 & 1,09 & 1,5 & 0,15 & 383 & 3 & 198 & 152 & 59 & 160 & 122 & 28 \\
\hline BTM5 & 72,9 & 0,9 & 13,5 & 5,5 & 0,15 & 1,9 & 1,6 & 1,71 & 1,7 & 0,09 & 369 & 3,0 & 269 & 158 & 59 & 108 & 113 & 24 \\
\hline BTM7 & 67,4 & 1,0 & 15,7 & 7,0 & 0,14 & 2,9 & 2,4 & 1,16 & 2,0 & 0,15 & 410 & 10,0 & 288 & 200 & 81 & 94 & 144 & 34 \\
\hline BTM8 & 67,6 & 0,8 & 15,8 & 6,6 & 0,12 & 3,4 & 1,4 & 1,71 & 2,3 & 0,13 & 461 & 10,0 & 187 & 183 & 78 & 86 & 134 & 25 \\
\hline HSK-1 & 50,7 & 0,9 & 13,8 & 7,3 & 0,14 & 6,2 & 17,4 & 1,10 & 2,1 & 0,25 & 419 & 21,0 & 260 & 174 & 78 & 321 & 120 & 30 \\
\hline HSK-2B & 63,7 & 0,8 & 13,2 & 6,1 & 0,10 & 4,1 & 7,1 & 2,57 & 1,9 & 0,17 & 382 & 19,0 & 332 & 106 & 64 & 199 & 112 & 28 \\
\hline HSK-3 & 60,1 & 0,9 & 13,5 & 6,7 & 0,12 & 4,8 & 9,5 & 2,22 & 1,9 & 0,20 & 388 & 23,0 & 360 & 129 & 65 & 228 & 121 & 33 \\
\hline DER1 & 39 & 0,7 & 10,4 & 5,2 & 0,0 & 6,9 & 34,0 & 0, & 2,0 & 0,45 & 298 & 0,0 & 68 & 77 & 58 & 14 & 74 & 16 \\
\hline DER2 & 39 & 0,7 & 10,8 & 5,3 & 0,10 & 7,1 & 33,1 & 0,8 & 2,1 & 0,44 & 305 & 0 , & 65 & 82 & 58 & 144 & 75 & 11 \\
\hline DER3 & 37,6 & 0,6 & 8,78 & 4,2 & 0,08 & 5,3 & 40,2 & 0,95 & 1,9 & 0,38 & 277 & 0,0 & 37 & 38 & 46 & 12 & 56 & 13 \\
\hline DER4 & 37,3 & 0,6 & 9,63 & 4,8 & 0,10 & 8,3 & 36,2 & 0,7 & 1,9 & 0,38 & 284 & 0,0 & 73 & 75 & 51 & 132 & 71 & 14 \\
\hline HN2B & 49 & 0,8 & 13, & 6 & 0, & 5,3 & 2 & 0 , & 1,7 & 0,16 & 334 & 0,0 & 209 & 201 & 68,4 & 441 & 132 & 29 \\
\hline VSI & 50,5 & 0,9 & 13,5 & 6,8 & 0,13 & 5,0 & 20,5 & 0, & 1,8 & 0,18 & 351 & 0,0 & 287 & 210 & 68,7 & 344 & 139 & 32 \\
\hline S2B & 51 & 0,9 & 13,6 & 6,7 & 0,12 & 5 , & 19,1 & 0 , & 1,9 & 0,21 & 358 & 0,0 & 257 & 215 & 68,9 & 342 & 143 & 33 \\
\hline RAD-1 & 47 & 1,0 & 11,5 & 6,7 & 0,1 & 5 , & 2 & 0 , & 1 , & 0 & 311 & 21,0 & 353 & 169 & 60,7 & 337 & 125 & 30 \\
\hline GEL-1 & 38,0 & 0,6 & 9,8 & 5,1 & 0,0 & 5,3 & 39,6 & 0,2 & 1,1 & 0,13 & 239 & 15,0 & 222 & 136 & 46 & 390 & 98 & 21 \\
\hline ASLO-1 & 51,3 & 0,9 & 12,6 & 6,4 & 0,12 & 5,0 & 20,9 & 0,50 & 1,8 & 0,23 & 333 & 19,0 & 284 & 155 & 69,9 & 414 & 114 & 31 \\
\hline HSB-III-B2 & 49,6 & 0,8 & 12,9 & 6,3 & 0,08 & 4,9 & 22,5 & 0,46 & 1,9 & 0,32 & 353 & 18,0 & 257 & 157 & 72 & 535 & 110 & 29 \\
\hline KAL-6 & 40,6 & 0,7 & 10,3 & 5,4 & 0,0 & 7,3 & 33,4 & 0,4 & 1,4 & 0,17 & 267 & 16,0 & 243 & 130 & 54,7 & 393 & 101 & 29 \\
\hline JERM-3 & 39,4 & 0,7 & 11,1 & 5,5 & 0,05 & 7,8 & 33,6 & 0,35 & 1,3 & 0,14 & 249 & 13,0 & 221 & 131 & 57,1 & 222 & 105 & 29 \\
\hline FAR-7 & 54,2 & 1,0 & 15, & 8.1 & 0.14 & 4, & 13,5 & 0,6 & 1, & 0,24 & 404 & 30,0 & 259 & 203 & 80,4 & 432 & 154 & 36 \\
\hline KHR-6 & 50,0 & 0,9 & 13,6 & 7,1 & 0,1 & 5,5 & 20 & 0,4 & 1,8 & 0 , & 323 & 24,0 & 299 & 199 & 75,9 & 325 & 129 & 31 \\
\hline WR-38 & 54,4 & 0,9 & 14,4 & 7,7 & 0,13 & 5,9 & 13,5 & 0,53 & 2,2 & 0,23 & 361 & 27,0 & 330 & 245 & 79,1 & 244 & 134 & 30 \\
\hline AY-37 & 55,0 & 0,7 & 10,9 & 5,2 & 0,12 & 3, & 20,9 & 1,28 & 1 , & 0,17 & 323 & 17,0 & 573 & 148 & 55 & 371 & 104 & 26 \\
\hline QM1 & 49,1 & 0,8 & 13,9 & 6,9 & 0,11 & 5,5 & 21,3 & 0,32 & 1,8 & 0,15 & 327 & 0,0 & 214 & 228 & 70,4 & 224 & 142 & 33 \\
\hline QP215 & 50,2 & 0,8 & 11,6 & 5,9 & 0,11 & 4,6 & 24,4 & 0,61 & 1,4 & 0,20 & 269 & 21,0 & 354 & 166 & 54,3 & 187 & 124 & 29 \\
\hline
\end{tabular}

Table 3. The major and trace element concentrations of clay samples from the Upper Tigris Valley and the Upper Khabur region. Concentration values are given in $\mathrm{Wt}$. \% for major and trace elements in ppm. 

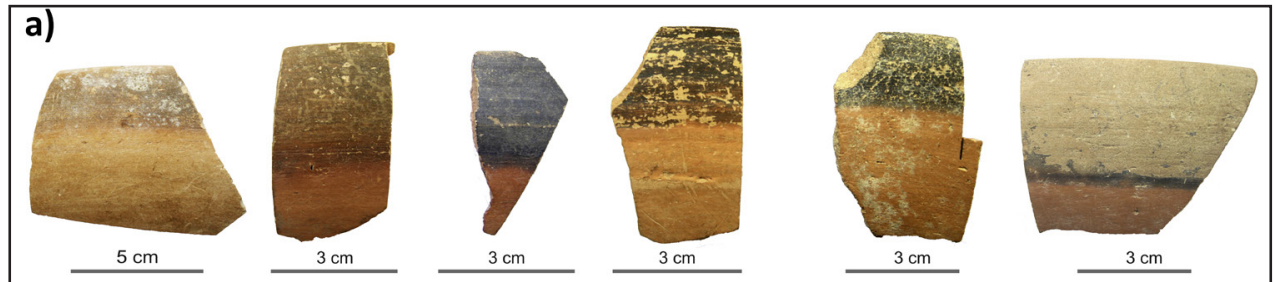

b)
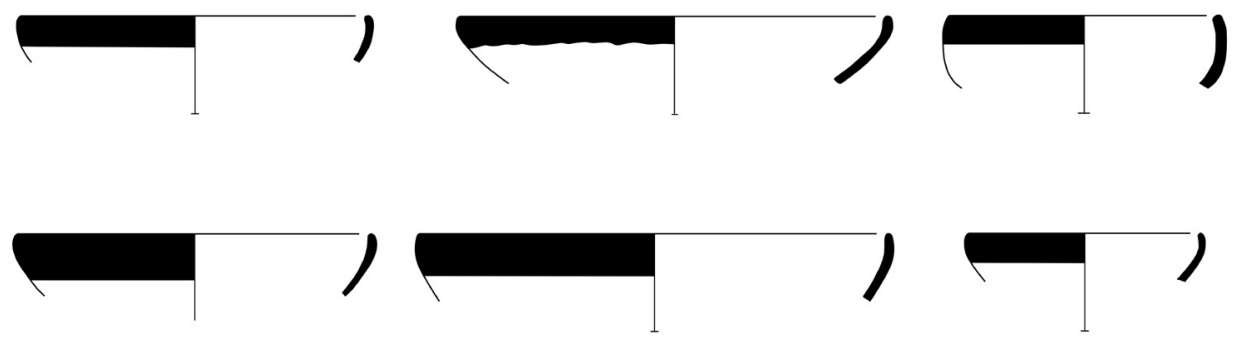

Fig. 1. a) Example sherds of DROB ware from the Upper Tigris and the Upper Khabur region, b) illustration of typical DROB ware (after Bianchi 2012).

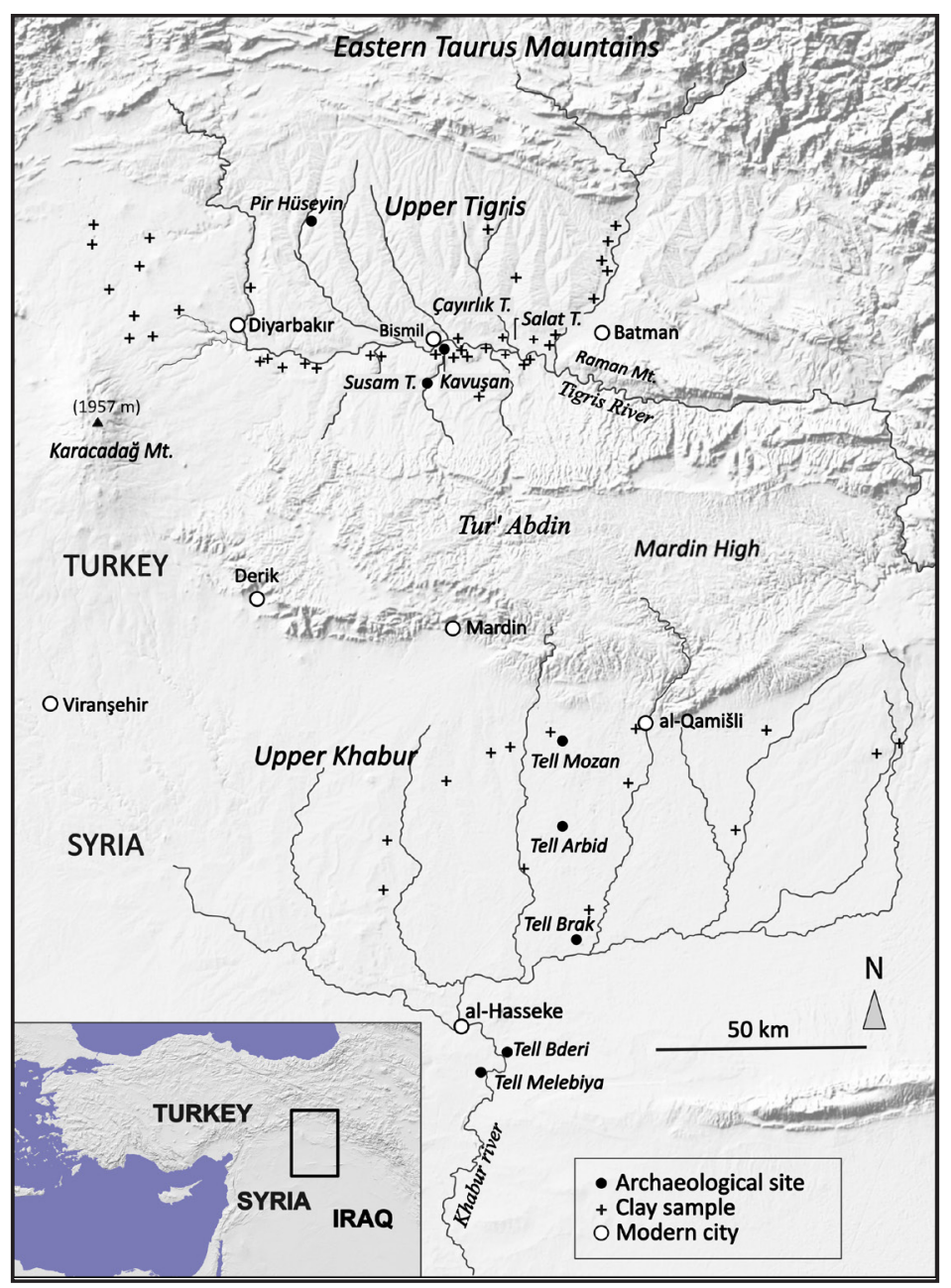

Fig. 2.

Topographic map of study area and distribution area of DROB ware in the Upper Khabur and the Upper Tigris. The map shows also archaeological sites and locations mentioned in the text, as well as location of reference clay samples used in the study. 

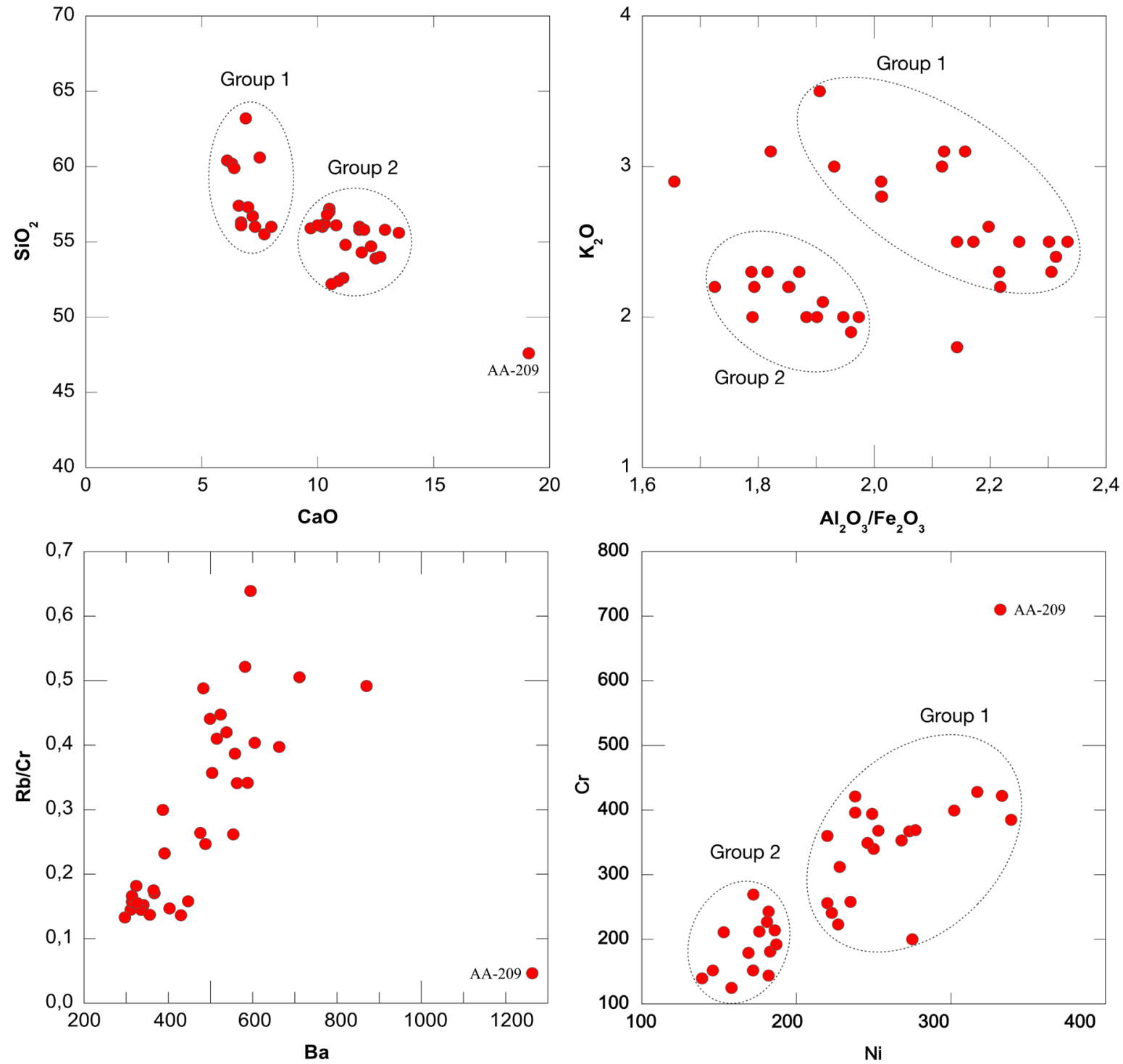

Fig. 3. Scatterplots of $\mathrm{SiO}_{2}$ vs. $\mathrm{CaO}, \mathrm{K}_{2} \mathrm{O}$ vs. $\mathrm{Al}_{2} \mathrm{O}_{3} / \mathrm{Fe}_{2} \mathrm{O}_{3^{\prime}} \mathrm{Rb} / \mathrm{Cr}$ vs. $\mathrm{Ba}$ and $\mathrm{Cr}$ vs. Ni of DROB ware from the Upper Tigris and Upper Khabur region. 

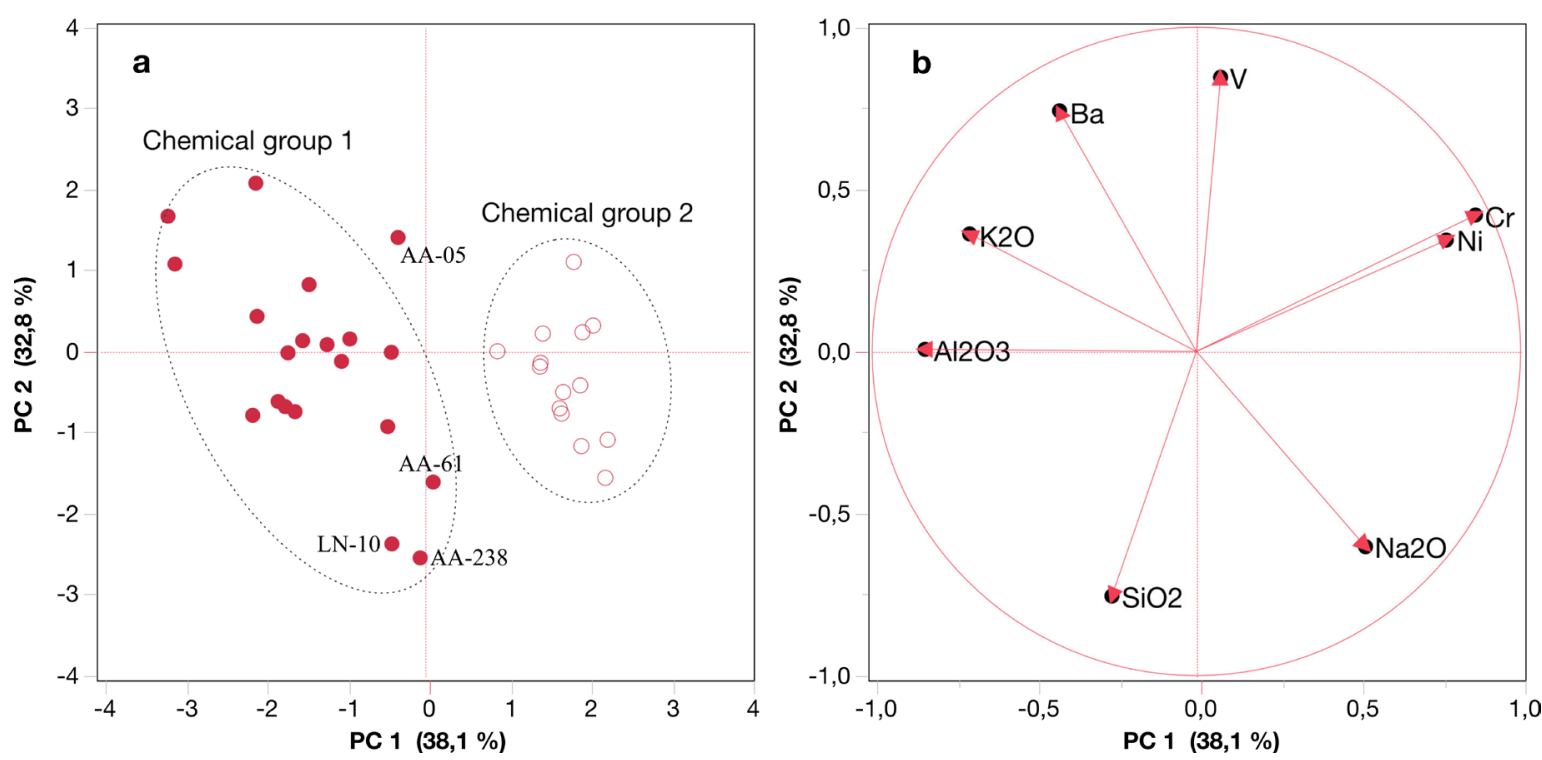

Fig. 4. a) Showing the scatter plot of the first two principal components (PC1 and PC2) and b) loading plots of analyzed DROB ware from the Upper Tigris Valley and the Upper Khabur region.

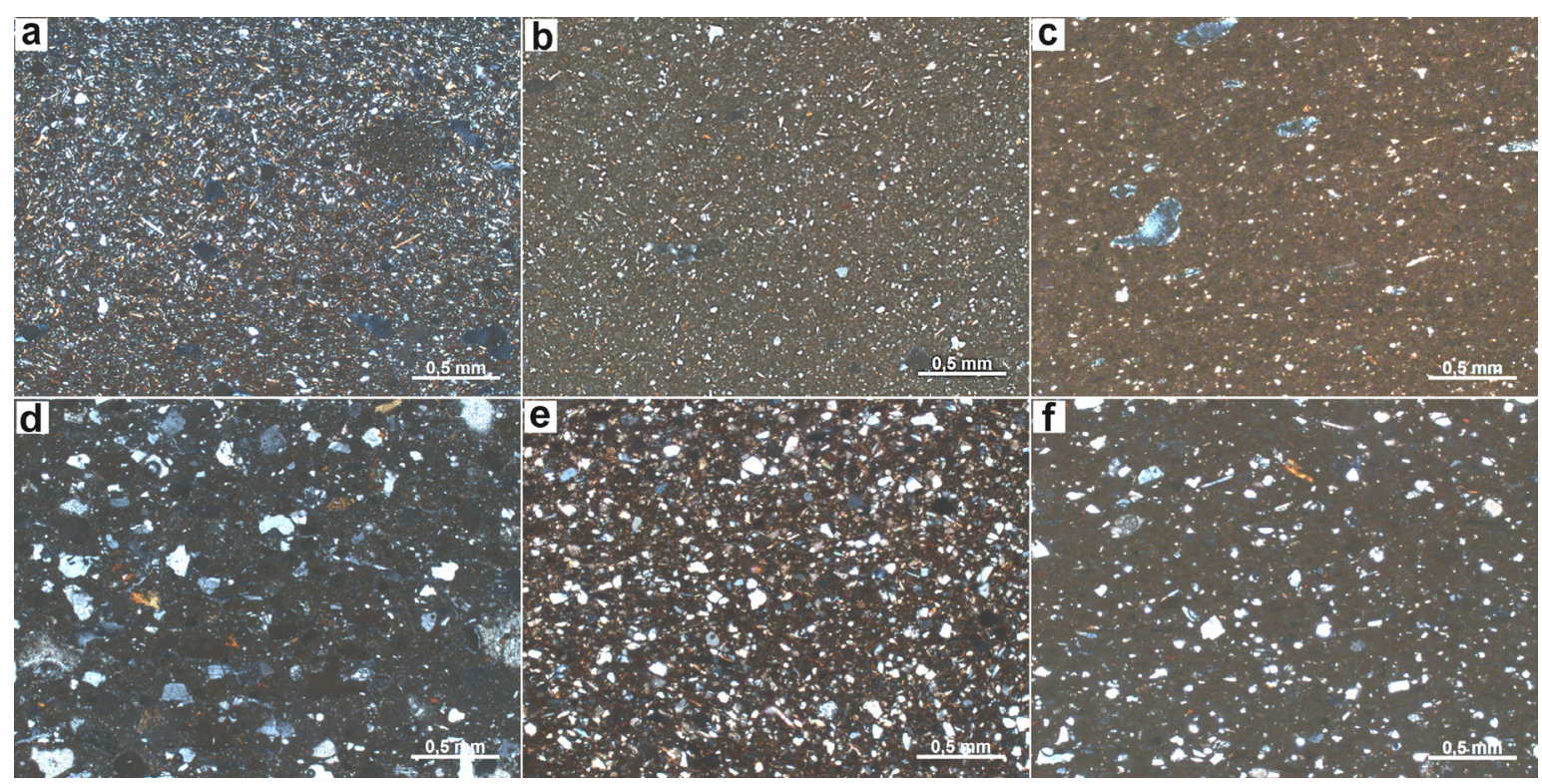

Fig. 5. Thin-section photomicrographs of DROB ware from the Upper Tigris and Upper Khabur, representing two different petrographic groups: petrographic group A and B. a: samples AA-240, b: AA-7 and c: AA-201 belong to the petrographic group $A$, showing fine fabric features with predominant fine quartz and needle-like muscovite inclusions, d: samples AA-226, e: AA-238 and f: AA-174 belong to the petrographic group B, showing moderate large fabric features with quartz and muscovite inclusions (All photomicrographs were taken with cross-polarized light, 5X). 

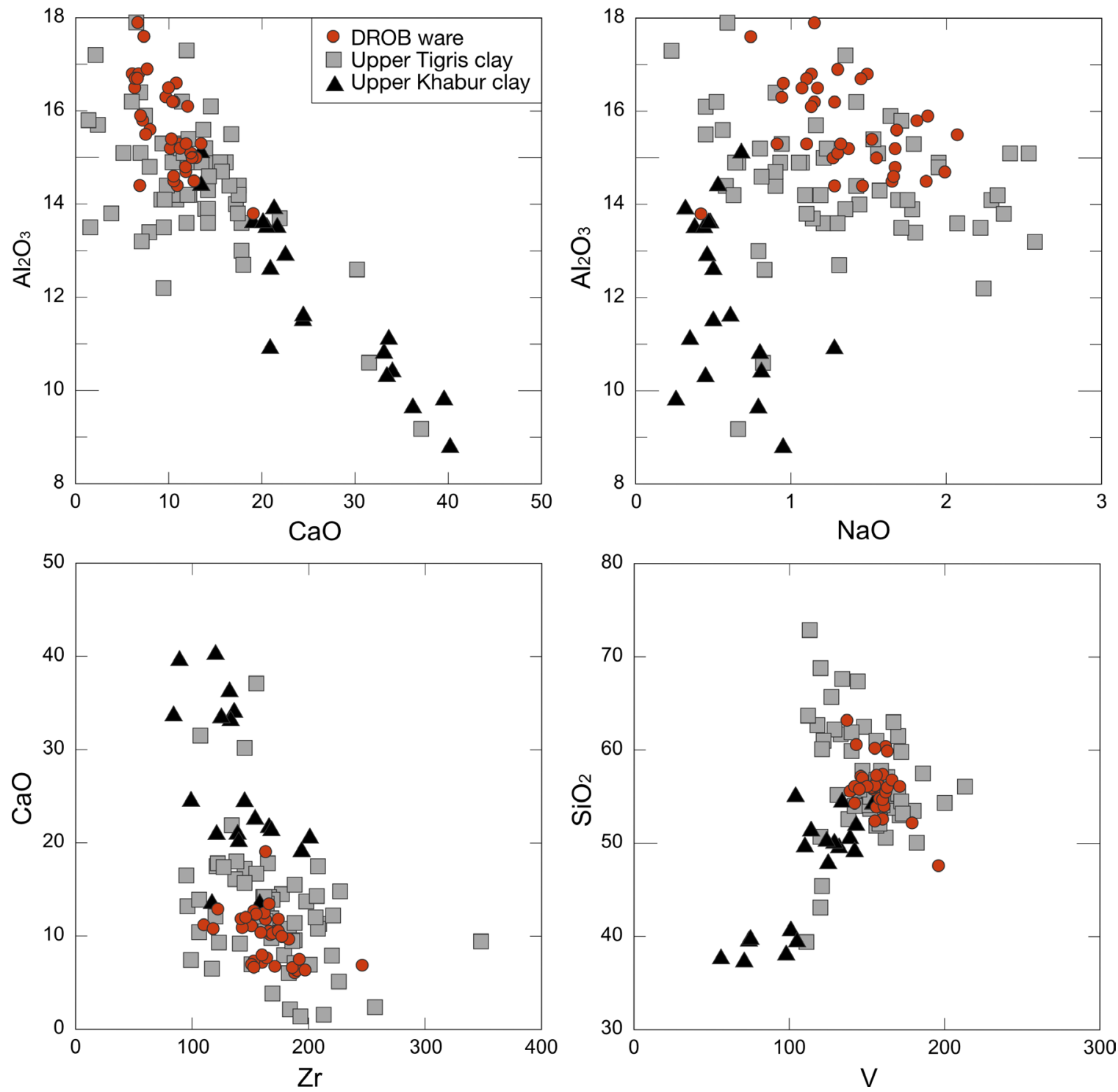

Fig. 6. Scatterplots of $\mathrm{CaO}$ vs. Al2O3, Na2O vs. Al2O3, Zr vs. CaO and V vs. SiO2 of the DROB ware and clay samples from the Upper Khabur and Upper Tigris Valley, showing compositional similarity of DROB ware to the clay sample from the Upper Tigris. 

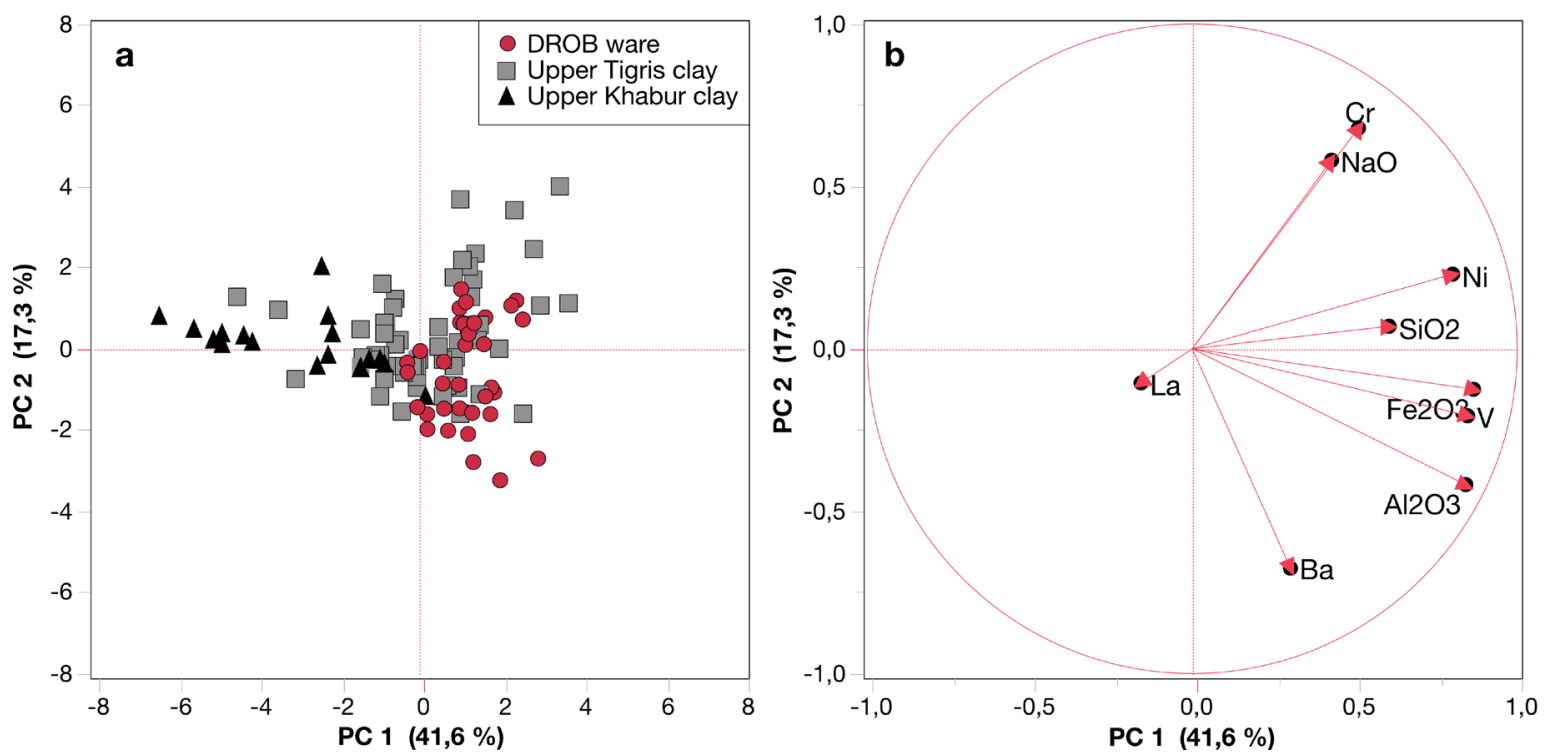

Fig. 7. a) Showing the scatter plot of first two principal components (PC1 and PC2) and loading plots (b) of analyzed DROB ware and reference clay samples from the Upper Tigris Valley and the Upper Khabur region.

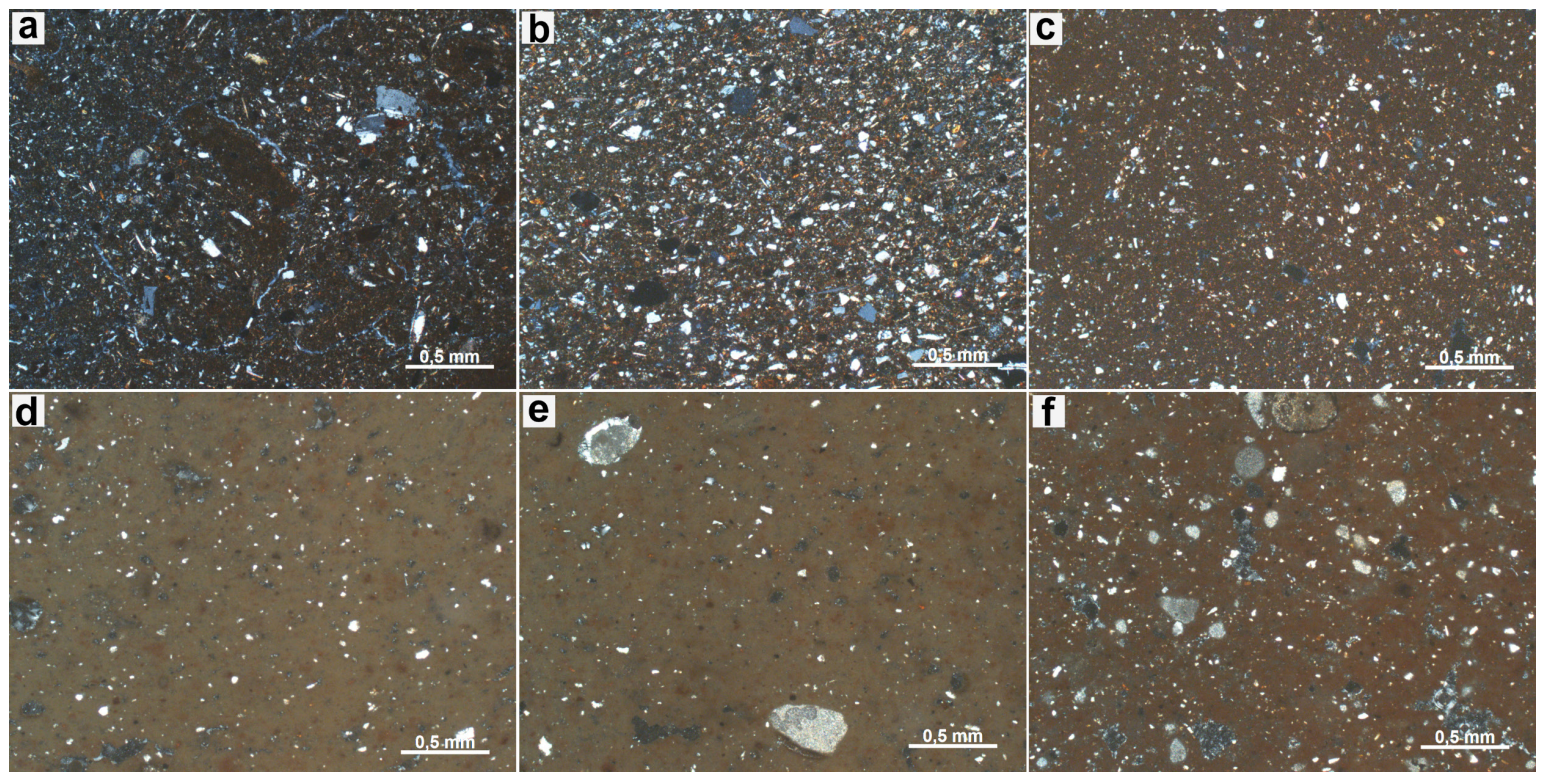

Fig. 8. Thin-section photomicrographs of selected reference clay samples from the Upper Tigris (a, b, c) and Upper Khabur (d, e, f), with different petrographic features. Clay samples from the Upper Tigris show predominate quartz inclusions and needle-like muscovite, whereas the clays from the Upper Khabur contain carbonate inclusions in high quantity and low quantity quartz (All photomicrographs were taken with cross-polarized light, 5X) . 